\title{
Investment and financing constraints in Iran
}

\author{
Hossein Etemadi, Fatemeh Baghiyan \\ Department of accountancy, Azad University of Gazvin, Gazvin baragin, Iran
}

\section{Email address:}

etemadih@modares.ac.ir(H. Etemadi),parbag@yahoo.com(F. Baghiyan)

\section{To cite this article:}

Hossein Etemadi, Fatemeh Baghiyan, Investment and Financing Constraints in Iran. International Journal of Economics, Finance and Management Sciences, Vol. 1, No. 5, 2013, pp. 252-257. doi: 10.11648/j.ijefm.20130105.17

\begin{abstract}
Since the level of fixed investment is costly for firms, they always search for ways to maintain it; however, financing constraints prevent the realization of this goal. In this article, a panel of over 134 stock firms over the period 2005-2011 was used to study the linkages between investment in fixed and working capital and financing constraints. To this end we have analyzed the relation between investment, cash flow, tangible fixed assets, working capital, and fixed investment. The results obtained indicate that an active management of working capital may help firms alleviate the effects of financing constraints on fixed investment. Nevertheless, they did not examine the input of working capital management of the company.
\end{abstract}

Keywords: Investment, Cash Flow, Tangible Fixed Assets, Fixed Investment, Working Capital Management

\section{Introduction}

In the last three decades, the Chinese economy has been characterized by persistently high fixed investment rates and phenomenal growth rates [1]. Considering that the Chinese financial system is poorly developed, this can been seen as a puzzle [2]. Several authors have tried to find explanations for it. Among these, Ayyagari [3] focused on the role of informal finance, and concluded that it is not because of their access to informal financial sources that Chinese firms were able to grow, despite limited access to external financing. Cull [4] concluded that access to trade credit did not play a significant role in explaining this puzzle. Guariglia [5] demonstrated that the Chinese miracle growth was driven by highly productive private firms, which were able to accumulate very high cash flows.

According to their study, this abundant internal financing allowed Chinese private firms to manage to finance their high growth rates, despite their limited ability to obtain external financing.

The current study was conducted on a panel of 134 stock firms over the period 2005-2011. We initially ran fixed investment and working capital investment regressions as a function of cash flow. Then we focused on investment in fixed capital, which is a significant determinant of growth, both generally (Bernanke and Gurkanyan [6]; Bond and Schiantarelli, [7] and in China (Ding and Knight, [8]

Active components of working capital can decrease financing constraints on fixed investment firms. Research findings show that firms with high working capital display high sensitivities to investment in working capital to cash flow (WKS) and low sensitivities to investment in fixed capital to cash flow (FKS). We found that, despite severe external financing constraints, those firms with low FKS and high WKS exhibit the highest fixed investment rates.

All companies, hoping to improve company performance focus on seven main accounting practices. The level of fixed investment is costly for firms, so they search for ways to maintain it. Financing constraints, however, prevent the realization of this goal. Because companies cannot without cost, Eliminate fluctuations in cash flow from foreign funds. Limited companies can change their working capital, Effects of sudden changes in cash flows on fixed investment eliminate with putting investment in working capital in the negative level. That In this case, the working capital adjustment costs, followed by the amount of smoothing depends on the initial capital investment is involved, the variable that helps to strengthen the company's balance sheet. But if companies are faced with financial constraints, investment in fixed capital investment of available funds will be in opposition. In this case, the fixed capital investment as endogenous variables in is egression of fixed capital coefficient will be negative. The second empirical prediction is that have not diminished recent studies attention to the profound impact of financial constraints on investment. The coefficient of cash flow in fixed investment regressions that in many recent studies come. Only short-term impact of the shock of cash flow 
after change optimizes investments will do. The fixed capital investment as a (an important determinant of growth), and in particular the role of working capital management as well as the explanation of why, despite some significant limitations, they have been able to finance their investment in a very high rate, be examined.

Proper management working capitals can financial constraints investment in fixed assets decrease.

\section{Four Research Hypotheses}

1) There is a positive relationship between the change in operating cash flows and changes in fixed assets of the companies.

2) There is a negative relationship between the changes

1) $\left(\frac{\mathrm{I}_{\mathrm{it}}}{\mathrm{K}_{\mathrm{it}}}\right)=\beta_{0}+\beta_{1}\left(\frac{\mathrm{CF}_{\mathrm{it}}}{\mathrm{K}_{\mathrm{it}}}\right)+\beta_{2}$ Lev $+\beta_{3}$ Growth $+\beta_{4}$ size $+\varepsilon_{\mathrm{it}}$

2) $\left(\frac{I W K_{i t}}{K_{i t}}\right)=\beta_{0}+\beta_{1}\left(\frac{C F_{i t}}{K_{i t}}\right)+\beta_{2} L e v+\beta_{3}$ Growth $+\beta_{4} \operatorname{Size}+\varepsilon_{i t}$

3) $\left(\frac{I_{i t}}{K_{i t}}\right)=\beta_{0}+\beta_{11}\left(\frac{\mathrm{CF}_{\mathrm{it}}}{\mathrm{K}_{\mathrm{it}}}\right)+\beta_{12}\left(\frac{C F_{i t}}{K_{i t}}\right)^{*} L O W W K_{i t}{ }^{\prime} H I G H W K_{i t}+\beta_{2} L e v+\beta_{3}$ Growth $+\beta_{4}$ Size $+\varepsilon_{i t}$

4) $\left(\frac{I W K_{i t}}{K_{i t}}\right)=\beta_{0}+\beta_{11}\left(\frac{\mathrm{CF}_{i \mathrm{t}}}{\mathrm{K}_{\mathrm{it}}}\right)+\beta_{12}\left(\frac{C F_{i t}}{K_{i t}}\right)^{*} L O W W K_{i t}^{\prime} H I G H W K_{i t}+\beta_{2} L e v+\beta_{3}$ Growth $+\beta_{4}$ Size $+\varepsilon_{i t}$

\subsection{Baseline Specification and Estimation Methodology and Analysis}

In scientific studies, analyzing the statistical data collected from the statistical samples, are considered an important step of the research, because the researcher reaches the final results, in this stage. Meaning that by using a research method, the data analyzed, the test hypothesis tested and eventually the final result would be ready for the report.

In this season, the data related to the companies over the time span 1385-1390 are analyzed, so that the connection between its variables could be revealed for the test hypothesis. The gathered data were first calculated via the Excel software, afterwards analyzed via the SPSS18 and EVIEWS6 software.

The data analysis at the descriptive statistics section was initiated by calculating the central indexes, such as the mean, median and standard deviation, and the skewness and elongation skewness distribution indexes. These indexes were done separately and completely. Furthermore, the dependent variable normality test was analyzed, which was done via the Kolmogorov - Smirnov test. For the means of analyzing the model data, the panel analysis method was used. The presence or absence of effects (constant or random) was studied in the models, so in working capital and the change in operating cash flows of the companies.

3) There is a no significant relationship between Investments in fixed assets low sensitivity to changes in operating cash flows, working capital changes.

4) There is a positive relationship between Investments in a high sensitivity to changes in working capital and operating cash flow and working capital.

\subsection{Research Methods and Processes}

An active management of working capital may help firms to alleviate the effects of financing constraints on fixed investment.

\section{The Following Equations are Studied}

eventually the most suitable model was estimated.

The deduction basis was on the significance level or the $\mathrm{P}$-value, thus that whenever the odds ratio or significant level are less than $0.05 \%$, zero becomes significant at the confidence level of $95 \%$.

\section{Data Description}

In the table below, the central indexes including the mean and median and scattering parameters such as standard deviation, skewness, and strain are measured for different variables. The mean being higher than the median indicates of big spots in the data, because the mean is affected by these amounts, in these cases the data distribution has a right skewness, for example the distributions of the (High WK, Low WK, CF/K, and DEBT) variables have a right skewness, and in some cases, a left skewness. The distribution of no variable has a left skewness, and if the mean and median of the variables are close to each other, the variable distribution is symmetric. This property is very important, because being symmetric is one of the features of a normal distribution, which shall be explained at the next article (the amount of skewness and strains are 0 in a normal distribution). 
Table1: Descriptive Statistics for Variables

\begin{tabular}{|c|c|c|c|c|c|c|c|c|c|}
\hline maximum & minimum & strain & skewers & $\begin{array}{l}\text { Standard, } \\
\text { deviation }\end{array}$ & median & Mean & $\begin{array}{l}\text { Observation } \\
\text { Perth }\end{array}$ & observations & variables \\
\hline $1 / 00$ & $-2 / 02$ & $0 / 32$ & $-0 / 96$ & $0 / 33$ & $0 / 07$ & $0 / 09$ & 2 & 802 & $\mathrm{I} / \mathrm{k}$ \\
\hline $5 / 98$ & $-3 / 78$ & $0 / 36$ & $0 / 31$ & $1 / 03$ & $0 / 26$ & $0 / 42$ & 3 & 801 & IWK $/ \mathrm{k}$ \\
\hline $4 / 26$ & $-2 / 33$ & $9 / 29$ & $1 / 65$ & $0 / 65$ & $0 / 02$ & $0 / 07$ & 0 & 804 & $\mathrm{CF} / \mathrm{k}$ \\
\hline $2 / 38$ & $-1 / 66$ & $29 / 05$ & $2 / 00$ & $0 / 25$ & $0 / 00$ & $0 / 00$ & 0 & 804 & $\begin{array}{l}\text { CF/K*Low } \\
\text { wk,Highwk }\end{array}$ \\
\hline $8 / 52$ & $4 / 25$ & $0 / 92$ & $0 / 71$ & $0 / 65$ & $5 / 54$ & $5 / 56$ & 0 & 804 & $\log$ Size \\
\hline $0 / 95$ & $0 / 00$ & $14 / 22$ & $3 / 30$ & $0 / 12$ & $0 / 06$ & $0 / 10$ & 0 & 804 & DEBT \\
\hline $2 / 97$ & $-1 / 00$ & $8 / 75$ & $1 / 51$ & $0 / 36$ & $0 / 14$ & $0 / 16$ & 0 & 804 & Growth \\
\hline $2 / 03$ & $-2 / 60$ & $2 / 05$ & $-0 / 13$ & $0 / 69$ & $-0 / 04$ & $-0 / 11$ & 0 & 804 & FKS \\
\hline $5 / 46$ & $-3 / 10$ & $3 / 12$ & $0 / 87$ & $1 / 37$ & $0 / 13$ & $0 / 29$ & 0 & 804 & WKS \\
\hline
\end{tabular}

Skewness of the dependent variables, I/K and the IWK $/ \mathrm{K}$ respectively0/96-and0/31, which is similar to the distribution of this variable is normally distributed, the variables are distributed approximately symmetrical.

\subsection{Analysis Panel}

for data analysis, data integration panel (Panel) without fixed effects, fixed effects and random effects was used. Fixed or random effects model to determine the suitability of Lymr test (Chow) test was used Hausman.

\subsection{The Process of Choosing the Right Model}

First, there is no effect of the model is tested (test Lymr).

Second, the model with random effects vs. fixed effects model is test (Hausmantest).

Finally, between the three models: without effects model, with fixed effects and random effects model and the best model is selected.

And the significance of each independent variable and control will be discussed.

Before fitting models using Chow tests or Lymr Hausman test model is suitable to estimate the model selected.

\subsection{Model is Given as Follows}

1) There is a positive relationship between the change in operating cash flows and changes in fixed assets of the companies.

$$
\left(\frac{I_{i t}}{K_{i t}}\right)=\beta_{0}+\beta_{1}\left(\frac{C_{\text {it }}}{K_{\text {it }}}\right)+\beta_{2} \text { Lev }+\beta_{3} \text { Growth }+\beta_{4} \text { size }+\varepsilon_{\text {it }}(1)
$$

Null hypothesis and the assumption of the model is as follows:

$$
\left\{\begin{array}{l}
H_{0}: \beta_{1} \leq 0 \\
H_{1}: \beta_{1}>0
\end{array}\right.
$$

$\begin{cases}H_{0}: & \text { The model is suitable for } \\ H_{1}: & \text { integration }\end{cases}$

\begin{tabular}{|c|c|c|c|c|}
\hline \multicolumn{5}{|c|}{ Dependent Variable:I/k } \\
\hline \multicolumn{5}{|c|}{ Method: Pooled Least Squares } \\
\hline \multicolumn{5}{|c|}{ Date: 04/08/13 Time: 21:01 } \\
\hline \multicolumn{5}{|c|}{ Sample: 13851390} \\
\hline \multicolumn{5}{|c|}{ Included observations: 6} \\
\hline \multicolumn{5}{|c|}{ Cross-sections included: 134} \\
\hline \multicolumn{5}{|c|}{ Total pool (unbalanced) observations: 802} \\
\hline \multicolumn{5}{|c|}{ White cross-section standard errors \& covariance (d.f. corrected) } \\
\hline Prob. & t-Statistic & Std. Error & Coefficient & Variable \\
\hline $0 / 353$ & $0 / 930$ & 0/098 & 0/091 & $\mathrm{C}$ \\
\hline $0 / 000$ & $4 / 573$ & $0 / 018$ & $0 / 083$ & $\mathrm{CF} / \mathrm{k}$ \\
\hline $0 / 695$ & $-0 / 393$ & $0 / 020$ & $-0 / 008$ & $\log$ Size \\
\hline $0 / 001$ & $3 / 417$ & $0 / 107$ & $0 / 365$ & DEBT \\
\hline $0 / 525$ & $0 / 636$ & $0 / 034$ & $0 / 022$ & Growth \\
\hline $0 / 093$ & Mean dependent var & & $0 / 045$ & R-squared \\
\hline $0 / 329$ & S.D. dependent var & & $0 / 040$ & Adjusted R-squared \\
\hline $0 / 577$ & Akaike info criterion & & $0 / 322$ & S.E. of regression \\
\hline $0 / 606$ & Schwarz criterion & & $82 / 591$ & Sum squared reside \\
\hline $0 / 588$ & Hannan-Quinn criter. & & $-226 / 432$ & Log likelihood \\
\hline \multirow[t]{2}{*}{$1 / 935$} & Durbin-Watson stat & & $9 / 406$ & F-statistic \\
\hline & & & $0 / 000$ & Prob(F-statistic) \\
\hline
\end{tabular}

Table 2: Fixed Effects Model 
2) There is a negative relationship between the changes in working capital and the change in operating cash flows of the companies.

$$
\left(\frac{I W K_{i t}}{K_{i t}}\right)=\beta_{0}+\beta_{1}\left(\frac{C F_{i t}}{K_{i t}}\right)+\beta_{2} L e v+\beta_{3} \text { Growth }+\beta_{4} \text { Size }+\varepsilon_{i t}
$$

Null hypothesis and the assumption of the model are as follows:

$$
\begin{aligned}
& \begin{cases}H_{0}: \beta_{1} \geq 0 \\
H_{1}: \beta 1<0\end{cases} \\
& \begin{cases}H_{0}: & \text { The model is suitable for } \\
H_{1}: & \text { integration }\end{cases} \\
& \text { Effects model is } \\
& \text { appropriate }
\end{aligned}
$$

\begin{tabular}{|c|c|c|c|c|}
\hline \multicolumn{5}{|c|}{ Dependent Variable: IWK/k } \\
\hline \multicolumn{5}{|c|}{ Method: Pooled Least Squares } \\
\hline \multicolumn{5}{|c|}{ Date: 04/08/13 Time: 21:02 } \\
\hline \multicolumn{5}{|c|}{ Sample: 13851390} \\
\hline \multicolumn{5}{|c|}{ Included observations: 6} \\
\hline \multicolumn{5}{|c|}{ Cross-sections included: 134} \\
\hline \multicolumn{5}{|c|}{ Total pool (unbalanced) observations: 801} \\
\hline Prob. & t-Statistic & Std. Error & $\begin{array}{l}\text { Coefficien } \\
\mathrm{t}\end{array}$ & Variable \\
\hline $0 / 001$ & $3 / 339$ & $0 / 288$ & $0 / 962$ & $\mathrm{C}$ \\
\hline $0 / 393$ & $0 / 855$ & $0 / 036$ & $0 / 030$ & $\mathrm{CF} / \mathrm{k}$ \\
\hline $0 / 056$ & $-1 / 911$ & $0 / 051$ & $-0 / 098$ & $\log$ Size \\
\hline $0 / 176$ & $-1 / 356$ & $0 / 319$ & $-0 / 433$ & DEBT \\
\hline $0 / 000$ & $3 / 575$ & $0 / 067$ & $0 / 239$ & Growth \\
\hline \multicolumn{5}{|c|}{ Effects Specification } \\
\hline \multicolumn{5}{|c|}{ Cross-section fixed (dummy variables) } \\
\hline $0 / 416$ & \multicolumn{2}{|c|}{ Mean dependent var } & $0 / 697$ & R-squared \\
\hline $1 / 031$ & \multicolumn{2}{|c|}{ S.D. dependent var } & $0 / 634$ & Adjusted R-squared \\
\hline $2 / 048$ & \multicolumn{2}{|c|}{ Akaike info criterion } & $0 / 623$ & S.E. of regression \\
\hline $2 / 855$ & \multicolumn{2}{|c|}{ Schwarz criterion } & $257 / 608$ & Sum squared reside \\
\hline $2 / 358$ & \multicolumn{2}{|c|}{ Hannan-Quinn criter. } & $-682 / 233$ & Log likelihood \\
\hline \multirow[t]{2}{*}{$1 / 738$} & \multirow{2}{*}{\multicolumn{2}{|c|}{ Durbin-Watson stat }} & $11 / 122$ & F-statistic \\
\hline & & & $0 / 000$ & Prob(F-statistic) \\
\hline
\end{tabular}

Table 3: Model with Random Effects

3) There is a no significant relationship between Investments in fixed assets low sensitivity to changes in operating cash flows, working capital changes.

$$
\begin{array}{r}
\left(\frac{I_{i t}}{K_{i t}}\right)=\beta_{0}+\beta_{11}\left(\frac{\mathrm{CF}_{i \mathrm{t}}}{\mathrm{K}_{\mathrm{it}}}\right)+\beta_{12}\left(\frac{C F_{i t}}{K_{i t}}\right)^{*} L O W W K_{i t^{\prime} H I G H W K_{i t}+} \\
\beta_{2} \text { Lev }+\beta_{3} \text { Growth }+\beta_{4} \text { Size }+\varepsilon_{i t}(3)
\end{array}
$$

\begin{tabular}{|c|c|c|c|c|}
\hline \multicolumn{5}{|c|}{ Dependent Variable:I/k } \\
\hline \multicolumn{5}{|c|}{ Method: Pooled Least Squares } \\
\hline \multicolumn{5}{|c|}{ Date: 04/08/13 Time: 21:04 } \\
\hline \multicolumn{5}{|c|}{ Sample: 13851390} \\
\hline \multicolumn{5}{|c|}{ Included observations: 6} \\
\hline \multicolumn{5}{|c|}{ Cross-sections included: 134} \\
\hline \multicolumn{5}{|c|}{ Total pool (unbalanced) observations: 802} \\
\hline Prob. & t-Statistic & Std. Error & $\begin{array}{l}\text { Coefficien } \\
\mathrm{t}\end{array}$ & Variable \\
\hline $0 / 462$ & $0 / 737$ & 0/098 & $0 / 072$ & $\mathrm{C}$ \\
\hline $0 / 004$ & $2 / 915$ & $0 / 020$ & $0 / 058$ & $\mathrm{CF} / \mathrm{k}$ \\
\hline $0 / 004$ & $2 / 889$ & $0 / 050$ & $0 / 145$ & $\begin{array}{l}\text { CF/K*Low } \\
\text { wk,Highwk }\end{array}$ \\
\hline $0 / 806$ & $-0 / 246$ & $0 / 017$ & $-0 / 004$ & $\log$ Size \\
\hline $0 / 000$ & $3 / 792$ & 0/096 & $0 / 363$ & DEBT \\
\hline $0 / 452$ & $0 / 752$ & $0 / 032$ & $0 / 024$ & Growth \\
\hline $0 / 093$ & \multicolumn{2}{|c|}{ Mean dependent var } & $0 / 055$ & R-squared \\
\hline $0 / 329$ & \multicolumn{2}{|c|}{ S.D. dependent var } & $0 / 049$ & Adjusted R-squared \\
\hline $0 / 569$ & \multicolumn{2}{|c|}{ Akaike info criterion } & $0 / 320$ & S.E. of regression \\
\hline $0 / 604$ & \multicolumn{2}{|c|}{ Schwarz criterion } & $81 / 734$ & Sum squared reside \\
\hline $0 / 583$ & \multicolumn{2}{|c|}{ Hannan-Quinn criter. } & $-222 / 250$ & Log likelihood \\
\hline \multirow[t]{2}{*}{$1 / 940$} & \multirow{2}{*}{\multicolumn{2}{|c|}{ Durbin-Watson stat }} & $9 / 263$ & F-statistic \\
\hline & & & $0 / 000$ & Prob(F-statistic) \\
\hline
\end{tabular}

Null hypothesis and the assumption of the model are as follows:
$\left\{\begin{array}{l}H_{0}: \beta 12 \geq \beta 11 \\ H_{1}: \beta 12<\beta 11\end{array}\right.$

$\begin{cases}H_{0}: & \text { The model is suitable for } \\ H_{1}: & \text { integration }\end{cases}$

Effects model is

appropriate

Table 4: Model with Fixed Effects

4) There is a positive relationship between Investments in a high sensitivity to changes in working capital and operating cash flow and working capital.

$$
\begin{array}{r}
\left(\frac{I W K_{i t}}{K_{i t}}\right)=\beta_{0}+\beta_{11}\left(\frac{\mathrm{CF}_{\mathrm{it}}}{\mathrm{K}_{\mathrm{it}}}\right)+\beta_{12}\left(\frac{C F_{i t}}{K_{i t}}\right)^{*} L O W W K_{i t}{ }^{\prime} H I G H W K_{i t}+ \\
\beta_{2} L e v+\beta_{3} \text { Growth }+\beta_{4} \text { Size }+\varepsilon_{i t}(4)
\end{array}
$$

Null hypothesis and the assumption of the model are as follows:

$$
\begin{cases}H_{0}: & \text { The model is suitable for } \\ H_{1}: & \text { integration } \\ & \text { The model is suitable } \\ & \text { for interation }\end{cases}
$$

$$
\left\{\begin{array}{l}
H_{0}: \beta 12 \leq \beta 11 \\
H_{1}: \beta 12>\beta 11
\end{array}\right.
$$


Table 5: Model with Fixed Effects

\begin{tabular}{|c|c|c|c|c|}
\hline \multicolumn{5}{|c|}{ Dependent Variable: IWK/k } \\
\hline \multicolumn{5}{|c|}{ Method: Pooled Least Squares } \\
\hline \multicolumn{5}{|c|}{ Date: 04/08/13 Time: 21:05 } \\
\hline \multicolumn{5}{|c|}{ Sample: 13851390} \\
\hline \multicolumn{5}{|c|}{ Included observations: 6} \\
\hline \multicolumn{5}{|c|}{ Cross-sections included: 134} \\
\hline \multicolumn{5}{|c|}{ Total pool (unbalanced) observations: 801} \\
\hline Prob. & t-Statistic & Std. Error & Coefficient & Variable \\
\hline $0 / 001$ & $3 / 396$ & $0 / 290$ & $0 / 984$ & $\mathrm{C}$ \\
\hline $0 / 276$ & $1 / 090$ & $0 / 040$ & $0 / 044$ & $\mathrm{CF} / \mathrm{k}$ \\
\hline $0 / 470$ & $-0 / 723$ & $0 / 105$ & $-0 / 076$ & $\mathrm{CF} / \mathrm{K} *$ Low wk,Highwk \\
\hline $0 / 048$ & $-1 / 978$ & $0 / 051$ & $-0 / 102$ & $\log$ Size \\
\hline $0 / 173$ & $-1 / 366$ & $0 / 320$ & $-0 / 436$ & DEBT \\
\hline $0 / 000$ & $3 / 574$ & $0 / 067$ & $0 / 239$ & Growth \\
\hline \multicolumn{5}{|c|}{ Effects Specification } \\
\hline \multicolumn{5}{|c|}{ Cross-section fixed (dummy variables) } \\
\hline $0 / 416$ & Mean dependent var & & $0 / 697$ & R-squared \\
\hline $1 / 031$ & S.D. dependent var & & $0 / 634$ & Adjusted R-squared \\
\hline $2 / 050$ & Akaike info criterion & & $0 / 624$ & S.E. of regression \\
\hline $2 / 863$ & Schwarz criterion & & $257 / 405$ & Sum squared reside \\
\hline $2 / 362$ & Hannan-Quinn criter. & & $-681 / 918$ & Log likelihood \\
\hline \multirow[t]{2}{*}{$1 / 737$} & Durbin-Watson stat & & $11 / 037$ & F-statistic \\
\hline & & & $0 / 000$ & $\operatorname{Prob}(F$-statistic) \\
\hline
\end{tabular}

\section{Discussion}

\section{Row as Hypothesized Confirmed-Reject}

1) There is a positive relationship between the change in operating cash flows and changes in fixed assets of the companies. Confirmed

2) There is a negative relationship between the changes in working capital and the change in operating cash flows of the companies. Reject

3) There is a no significant relationship between Investments in fixed assets low sensitivity to changes in operating cash flows, working capital changes. Confirmed

4) There is a positive relationship between Investments in a high sensitivity to changes in working capital and operating cash flow and working capital. reject

\subsection{The Validity of the Model}

The validity of the estimated model to establish the necessary presuppositions for the most important model assumptions are:

1. normality of residuals

2. homogeneous variance

3. Lack of correlation residuals

4. There is no linear relationship between the outlier and influential

5. Lack of multi collinearity between independent variables

\section{In this Study, Test and Diagnostic Charts are examined to make Assumptions:}

1. Klmvgvrvf Smirnov test.

2. The estimated residual plot (not shown on the chart pattern is matching the variance of these curves is presented in the Appendix)

3. Test Durbin - Watson (values close to 2, indicating a lack Auto correlated)

4. Scatter Diagrams

5. The correlation matrix is used (in enclosed) 


\section{Conclusion}

We use a panel of over 804 stock firms-Years over the period 2005-2011 to analyze the linkages between investment in fixed and working capital and financing constraints. We analyze relation between Investment, cash flow, tangible fixed assets, capital working and fixed investment and this suggests that an active management of working capital may help firms to alleviate the effects of financing constraints on fixed investment.

We regress fixed and working capital investment on cash flow and find that those firms characterized by high working capital display high sensitivities of investment in working capital to cash flow, and (with the exception of foreign firms) low sensitivities of investment in fixed capital to cash flow. This suggests that they are able to use working capital to alleviate the Effects of cash flow shocks on fixed capital investment.

We then construct firm-level sensitivities of investment in fixed and working capital to cash flow, and analyze their determinants. We find that in the presence of fluctuations in cash flow, older, larger, and slow-growing firms typically adjust

Fixed capital investment, while smaller, younger, and fast growing firms tend to adjust working capital instead. Furthermore, firms with low cash flow, which is likely to face significant internal credit constraints, are particularly active in adjusting both their fixed and working capital investment, while highly leveraged firms with low collateral tend to adjust the latter more than the former. Combining the two sensitivities, we find that, the former. Combining the two sensitivities, we find that, Compared to the other groups, those firms with low FKS and high WKS are more externally financially constrained (being younger, smaller, more indebted, and less collateralized), have high investment opportunities (exemplified by their high sales growth rates), and high working capital. Yet, they also have the highest fixed investment to fixed capital ratios. Despite the financing constraints that they face, in the presence of cash flow shocks, these firms can maintain consistently high fixed investment these firms can maintain consistently high fixed investment levels by adjusting working capital more than fixed capital. An active working capital management may therefore be a means that Iranian's many financially constrained firms use to mitigate the constraints that they face.

\section{References}

[1] Sai, D., Alessandra, G., John, K., 2012. Investment and financing constraints in china, Journal of banking \$ Finance $18,1-18$.

[2] Allen, F., Qian,J., Qian, M., 2005. Law, finance, and economic growth in China, Journal of Financial Economics $77,57-116$.

[3] Ayyagari, M., Demirgüç-Kunt, A., Maksimovic, V., 2010, Formal versus informal Finance: evidence from China.Review of Financial Studies 23, 3048-3097.

[4] Chen, H., Chen, S., 2012, Investment - cash flow sensitivity cannot be a good Measure of financial constraints: evidence from time-series. Journal of Financial Economics 103, 393410 .

[5] Guariglia, A., Liu, X., Song, L., 2011, internal finance and growth: microeconometric Evidence on Chinese firms, Journal of Development Economics 96 (1), 79-94.

[6] Bernanke, B., Gurkanyan, R., 2001. Is Growth Exogenous? Taking Mankiw, Romer, and Weil Seriously, National Bureau of Economic Research Annual, MIT Press, and Cambridge, Massachusetts.

[7] Bond, S., Schiantarelli, F., 2010, Capital accumulation and growth: a new look at Empirical evidence, Journal of Applied Econometrics 25, 1073-1099.

[8] Ding, S., Knight, J., 2011, why has China grown so fast?"The role of physical and human capital formation, Oxford Bulletin of Economics and Statistics 73, 141-174. 